\title{
A computational study on kinetics, mechanism and thermochemistry of gas-phase reactions of 3-hydroxy-2-butanone with $\mathrm{OH}$ radicals
}

\author{
NAND KISHOR GOUR ${ }^{\mathrm{a}}$, SATYENDRA GUPTA ${ }^{\mathrm{a}}$, BHUPESH KUMAR MISHRA ${ }^{\mathrm{b}, *}$ \\ and HARI JI SINGH ${ }^{\mathrm{a}, *}$ \\ ${ }^{a}$ Department of Chemistry, D. D.U. Gorakhpur University Gorakhpur, Uttar Pradesh, 273 009, India \\ ${ }^{b}$ Department of Chemical Sciences, Tezpur University Tezpur, Assam, 784 028, India \\ e-mail: bhupesh@tezu.ernet.in; hjschem50@gmail.com
}

MS received 13 March 2014; revised 26 May 2014; accepted 09 June 2014

\begin{abstract}
Theoretical investigation has been carried out on the kinetics and reaction mechanism of the gas-phase reaction of 3-hydroxy-2-butanone (3H2B) with $\mathrm{OH}$ radical using dual-level procedure employing the optimization at DFT(BHandHLYP)/6-311++G(d,p) followed by a single-point energy calculation at the $\operatorname{CCSD}(\mathrm{T}) / 6-311++\mathrm{G}(\mathrm{d}, \mathrm{p})$ level of theory. The pre- and post reactive complexes are also validated at entrance and exit channels, respectively. Thus reaction may be proceed via indirect mechanism. The intrinsic reaction coordinate (IRC) calculation has also been performed to confirm the smooth transition from a reactant to product through the respective transition states. The rate coefficients were calculated for the first time over a wide range of temperature $(250-450 \mathrm{~K})$ and described by the following expression: $\mathrm{k}_{\mathrm{OH}}=7.56 \times$ $10^{-11} \exp [-(549.3 \pm 11.2) / \mathrm{T}] \mathrm{cm}^{3}$ molecule ${ }^{-1} \mathrm{~s}^{-1}$. At $298 \mathrm{~K}$, our calculated rate coefficient $1.20 \times 10^{-11} \mathrm{~cm}^{3}$ molecule ${ }^{-1} \mathrm{~s}^{-1}$ is in good agreement with the experimental results. Our calculation indicates that $\mathrm{H}$-abstraction from $\alpha-\mathrm{C}-\mathrm{H}$ site of $3 \mathrm{H} 2 \mathrm{~B}$ is the dominant reaction channel. Using group-balanced isodesmic reactions, the standard enthalpies of formation for 3H2B and radicals generated by hydrogen abstraction are reported for the first time. The branching ratios of the different reaction channels are also determined. Also, the atmospheric lifetime of $3 \mathrm{H} 2 \mathrm{~B}$ is also calculated to be 1.04 days.
\end{abstract}

Keywords. Hydroxyketone; bond dissociation energy; isodesmic reactions; atmospheric lifetime.

\section{Introduction}

Carbonyls are known to be important intermediates in pyrolysis and combustion processes on saturated and unsaturated hydrocarbons. ${ }^{1,2}$ Wolfe et al. ${ }^{3}$ have shown in experimental studies that significant fractions of aldehydes and ketones are formed in the oxidation of isoprene. They are also directly emitted into the troposphere from biogenic ${ }^{4,5}$ and anthropogenic sources. ${ }^{6,7}$ They play a significant role in atmospheric chemistry due to their strong contribution in the formation of free radicals that are responsible for the oxidation of hydrocarbons. ${ }^{8}$ They are precursors of oxidants such as peroxyacyl nitrates (PANs), nitric acid and ozone. ${ }^{9}$ Ketones are a major class of organic chemicals and most common pollutants that are widely used in the industry as paints, solvents, etc. ${ }^{1}$ They are important in the chemistry of the atmosphere and in combustion systems from direct emissions and as intermediates. $\alpha$ Hydroxy ketone is a functional group entity of many biologically active natural products such as sugars and

*For correspondence antibiotics. ${ }^{10,11}$ Furthermore, $\alpha$-Hydroxy ketones are useful synthones in organic synthesis, with widely studied chemistry. ${ }^{12,13}$ The main loss process of hydroxycarbonyl in the troposphere is photolysis and reaction with $\mathrm{OH}$ radicals. ${ }^{14}$ Several studies ${ }^{15-20}$ have been performed on the kinetics and mechanism of the reaction of hydroxyacetone with $\mathrm{OH}$ radicals. 3-Hydroxy-2butanone, also known as acetoin or acetylmethylcarbinol, is a valuable flavour existing naturally in corn, kidney beans, peas and broccoli, and also the common intermediate for diacetyl and 2,3-butanediol synthesis. ${ }^{21}$ Wren and Glowa ${ }^{22}$ reported that radiolytic decomposition of methyl ethyl ketone produces 3-hydroxy-2-butanone. Aschmann et al. ${ }^{14}$ studied kinetics of $3 \mathrm{H} 2 \mathrm{~B}$ with $\mathrm{OH}$ radicals at $294 \pm 2 \mathrm{~K}$ and 740 Torr total pressure of purified air using relative rate methods during investigation and reported the rate coefficient, $\mathrm{k}_{\mathrm{OH}}=1.03$ $\times 10^{-11} \mathrm{~cm}^{3}$ molecule $\mathrm{s}^{-1} \mathrm{~s}^{-1}$. Recently, the gas-phase reaction of $3 \mathrm{H} 2 \mathrm{~B}$ with $\mathrm{OH}$ radicals has been studied experimentally by Messaadia et al. ${ }^{23}$ using the relative rate method and pyrex atmospheric chamber at 600 760 Torr of purified air by employing Smog chamber/ FTIR and LP/LIF techniques. The experimental rate 
constant for the reaction $3 \mathrm{H} 2 \mathrm{~B}$ with $\mathrm{OH}$ radicals at $298 \mathrm{~K}$ was reported to be $(0.96 \pm 0.3) \times 10^{-11}$ $\mathrm{cm}^{3}$ molecule ${ }^{-1} \mathrm{~s}^{-1} \cdot{ }^{23}$ As mentioned above, the study of the gas-phase reaction of $3 \mathrm{H} 2 \mathrm{~B}$ with atmospheric radicals is presently limited to two investigations at room temperature using the relative rate technique. ${ }^{14,23}$ To the best of our knowledge, there is no theoretical study of the title reaction so far. With this stimulus, ab-initio study on the title reaction was performed. 3-hydroxy-2-butanone (3H2B) possesses $\mathrm{H}$ atoms under four different environments and therefore the dominant pathways of the abstraction reactions could not be predicted using relative rate method. With this view point, the present study has been undertaken and an attempt has been made to find the dominant pathways and the branching ratio of $\mathrm{H}$-atom abstraction from $3 \mathrm{H} 2 \mathrm{~B}$ by $\mathrm{OH}$ radicals. Our calculations indicate that six reaction channels, four from the two terminals $-\mathrm{CH}_{3}$ groups and two reaction channels each from $-\mathrm{CH}$ and $-\mathrm{OH}$ groups are feasible as given below:

$$
\begin{aligned}
& \mathrm{CH}_{3} \mathrm{COCH}(\mathrm{OH}) \mathrm{CH}_{3}+\mathrm{OH} \rightarrow \mathrm{CH}_{2} \mathrm{COCH}(\mathrm{OH}) \mathrm{CH}_{3}+\mathrm{H}_{2} \mathrm{O} \quad \text { (R1a and R1b) } \\
& \rightarrow \mathrm{CH}_{3} \mathrm{COC}(\mathrm{OH}) \mathrm{CH}_{3}+\mathrm{H}_{2} \mathrm{O} \quad(R 2) \\
& \rightarrow \mathrm{CH}_{3} \mathrm{COCH}(\mathrm{O}) \mathrm{CH}_{3}+\mathrm{H}_{2} \mathrm{O} \quad(R 3) \\
& \rightarrow \mathrm{CH}_{3} \mathrm{COCH}(\mathrm{OH}) \mathrm{CH}_{2}+\mathrm{H}_{2} \mathrm{O} \quad(\mathrm{R} 4 \mathrm{a} \text { and } \mathrm{R} 4 \mathrm{~b})
\end{aligned}
$$

Based on the structure/reactivity relationship using AOPWIN model, it has been reported that $-\mathrm{CH}$ attached to hydroxyl group (reaction R2) should be more reactive than the other reaction channels for hydrogen abstraction reactions of $3 \mathrm{H} 2 \mathrm{~B}$ by $\mathrm{OH}$ radical. ${ }^{23}$ However, experimental studies provided only the total rate constant and it is difficult to predict the detailed mechanism and thermochemistry. Thus, for a better understanding of mechanistic pathways, kinetics and thermochemistry we must rely on quantum chemical methods. The aim of this paper is to have more accurate thermochemical data on a sound theoretical basis. Our aim is to find out the contribution of the individual channel to the overall rate constant and to provide an understanding of the kinetics involved in the reaction channels (R1-R4). Bond dissociation energies (BDEs) for breaking $\mathrm{C}-\mathrm{H}$ bonds are known to be strongly correlated with the observed reactivity trend for the hydrogen abstraction reactions. Thus, we present $\mathrm{BDE}$ for four types of $\mathrm{C}-\mathrm{H}$ bonds in $3 \mathrm{H} 2 \mathrm{~B}$. In addition, the knowledge of accurate enthalpy of formation $\left(\Delta_{\mathrm{f}} \mathrm{H}_{298}^{\circ}\right)$ for $3 \mathrm{H} 2 \mathrm{~B}$ and radicals generated is of vital importance to determine the thermodynamic properties and atmospheric modeling. However, no theoretical or experimental study on standard enthalpy of formation has not been reported so far for these species. Here, we predict the enthalpies of formation using isodesmic reactions by performing single-point energy calculation at high level of theory, $\operatorname{CCSD}(\mathrm{T})$ with geometry parameters obtained at the BHandHLYP/ $6-311++G(d, p)$ level. Finally, the comparison between theoretical and experimental rate constants is discussed.

\section{Computational Methods}

Geometry optimization and harmonic vibrational frequency calculation of the species involved in the reaction channels (R1-R4) were performed using hybrid density functional BHandHLYP ${ }^{24,25}$ level of theory using Pople's split-valence triple- $\zeta$ quality 6$311++\mathrm{G}(\mathrm{d}, \mathrm{p})$ basis set with single polarization and double diffuse functions on all atoms. The reactant and product complexes are also validated at the entrance and exit of each reaction channel. The choice of this DFT functional is best exemplified in earlier reports. ${ }^{26-29}$ In order to determine the nature of stationary points on the potential energy surface, vibrational frequency calculations were made at the same level of theory. The stationary points were identified to correspond to stable minima on the respective potential energy surface by ascertaining that all the harmonic vibrational frequencies were real and positive. The transition states in reaction channels (R1-R4) were characterized by the presence of only one imaginary frequency (NIMAG=1). At the same level, the minimum energy path (MEP) is obtained by intrinsic reaction coordinates (IRC) calculations. ${ }^{30}$ In order to ascertain that the transition of reactants to products via corresponding transition state was smooth, the minimum energy path (MEP) was obtained by intrinsic reaction coordinate (IRC) calculation performed using Gonzales-Schelgel steepest descent path in mass-weighted Cartesian with a gradient step-size of 0.01 (amu ${ }^{1 / 2}$-bohr). ${ }^{30}$ As the reaction energy barriers are very sensitive to the theoretical levels, the higher-order correlation corrected relative energies along with the density functional 
energies are necessary to obtain theoretically consistent reaction energies. Therefore, a potentially high-level method such as couple cluster with single and double excitations including approximate treatment for triple excitations $[\mathrm{CCSD}(\mathrm{T})]^{31,32}$ has been used for single point energy calculations using the same basis set as mentioned above. This dual level method, $\operatorname{CCSD}(\mathrm{T}) / /$ BHandHLYP is known to produce reliable kinetics and energetic results for $\mathrm{H}$-abstraction reactions. ${ }^{33-36}$ All the electronic calculations were performed using GAUSSIAN 09 program package. ${ }^{37}$

\section{Results and Discussion}

The detailed thermodynamic calculation performed at $\operatorname{CCSD}(\mathrm{T}) / / \mathrm{BH}$ andHLYP/6-311++G(d,p) level for reaction enthalpies $\left(\Delta_{\mathrm{r}} \mathrm{H}_{298}\right)$ and free energies $\left(\Delta_{\mathrm{r}} \mathrm{G}_{298}\right)$ associated with reaction channels (1-4) are listed in table 1 . Free energy values show that four reaction channels are exergonic $\left(\Delta_{\mathrm{r}} \mathrm{G}_{298}<0\right)$. The $\Delta_{\mathrm{r}} \mathrm{H}_{298}$ values as recorded in table 1 for reaction channels (R1-R4) reveal that each reaction channels are exothermic in nature and thermodynamic facile. The data given in table 1 suggest that product of reaction R2 is thermodynamically more stable than other reaction channels at $298 \mathrm{~K}$. Thus the hydrogen abstraction for reaction channel R2 may be thermodynamically more favourable than other reaction channels. There are four potential hydrogen abstraction sites of $3 \mathrm{H} 2 \mathrm{~B}$, namely the $\mathrm{CH}_{3} \mathrm{C}(\mathrm{O})$, $-\mathrm{CH}$ (attached to hydroxyl group), $-\mathrm{OH}$ and $-\mathrm{CH}_{3}$ group. It can be seen from the geometrical parameters and stereographical orientation that the hydrogen atoms in the two terminals $-\mathrm{CH}_{3}$ groups are not equivalent. One $\mathrm{H}$-atom is different from the other two in the $-\mathrm{CH}_{3}$ group. Four transition states (TS1a, TS1b, TS4a and TS4b) are therefore located for reaction channels (1 and 4), respectively from the two terminals $-\mathrm{CH}_{3}$ groups. Six transition states (TSs) are therefore, located for reactions of $3 \mathrm{H} 2 \mathrm{~B}$ with $\mathrm{OH}$ radicals. In the entrance channel for reactions $\mathrm{R} 1-\mathrm{R} 2$ pre-reactive complexes

Table 1. Thermochemical data at $298 \mathrm{~K}$ for reaction channels (R1-R4) calculated at $\operatorname{CCSD}(\mathrm{T}) / 6-311++\mathrm{G}(\mathrm{d}, \mathrm{p})$ and BHandHLYP/6-311++G(d,p) (within parentheses) levels of theory. All values are in $\mathrm{kcal} \mathrm{mol}^{-1}$.

\begin{tabular}{lcc}
\hline Reaction channels & $\Delta_{\mathrm{r}} \mathrm{H}_{298}^{\circ}$ & $\Delta_{\mathrm{r}} \mathrm{G}_{298}^{\circ}$ \\
\hline Reaction R1 & $-16.24(-18.92)$ & $-16.34(-18.96)$ \\
Reaction R2 & $-28.30(-32.76)$ & $-29.05(-33.45)$ \\
Reaction R3 & $-8.64(-12.23)$ & $-9.06(-12.59)$ \\
Reaction R4 & $-10.74(-11.69)$ & $-11.53(-12.42)$ \\
\hline
\end{tabular}

( $\mathrm{RC} 1$ and $\mathrm{RC} 2$ ) have been validated in the present work. However, for reaction channels R3 and R4, we have found the same reaction complex (RC3/RC4). Similarly, in the exit channels, there are also product complexes occurring before the release of the final products, which are labeled as PC followed by a number (PC1, PC2, PC3 and PC4). In pre-reactive complexes, hydrogen bonds are formed between the oxygen atom of hydroxyl radical with the hydrogen atom in $3 \mathrm{H} 2 \mathrm{~B}$ with bond distances of $2.726,2.95,2.776,2.02,3.28$ and $2.77 \AA$, respectively while the other bond lengths are very close to those in equilibrium structures. At the same time, the post-reaction hydrogen bonded complexes (PC1PC4) with less energy than the corresponding products are located at the exits of the reaction channels (R1-R4) which can be identified with relatively strong $\mathrm{C}-\mathrm{H}$... $\mathrm{O}$ and $\mathrm{O}-\mathrm{H}$...O bonds, as shown in figure 1 . So it is clear that the reaction channels (R1-R4) may proceed via indirect mechanisms. The search was made along the minimum energy path on a relaxed potential energy surface. The optimized structures of reactants, reactant complexes, transition states, product complexes and products at BHandHLYP/6-311++G(d,p) level of theory are shown in figure 1 . During the formation of transition states, the important structural parameters that have to be observed are one of the $\mathrm{C}-\mathrm{H}$ bonds of the leaving hydrogen and the newly formed bond between $\mathrm{H}$ and $\mathrm{O}$ atoms in the $\mathrm{OH}$ radical. From figure 1 , we can predict that in the optimized structure of transition states (TS1-TS4) for reaction channels (R1-R4), the length of the breaking $\mathrm{C}-\mathrm{H}$ bonds are found to be longer in the range of $10-15 \%$, whereas the newly formed $\mathrm{H}-\mathrm{O}$ bond is increased in the range of about $27-36 \%$. The fact that the elongation of forming bond is larger than that of the breaking bond indicates that the barrier of the reactions is near the corresponding reactants. This means the reaction will proceed via early transition state structure which is in consonance with Hammond's postulate ${ }^{38}$ applied to an exothermic hydrogen abstraction reaction.

Results obtained during frequency calculations for reactants, products and transition states involved in reaction channels (R1-R4) at BH and HLYP level of theory are recorded in table 2 . These results show that the reactants and products have stable minima on their potential energy surface characterized by the occurrence of only real positive vibrational frequencies while transition states TS1a, TS1b, TS2, TS3, TS4a and TS4b are characterized by the occurrence of only one imaginary frequency at 1705i, 2047i, 1086i, 2519i, 2027i and $1654 \mathrm{i} \mathrm{cm}^{-1}$, respectively at BHandHLYP level of theory. Visualization of the normal mode associated with the imaginary frequency gives a qualitative 


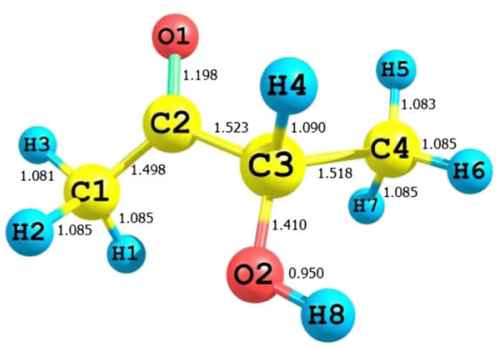

3H2B

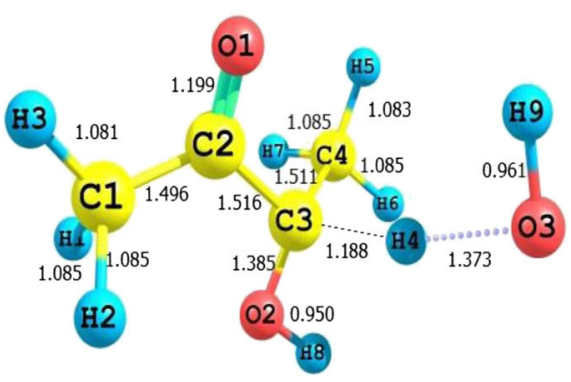

TS2

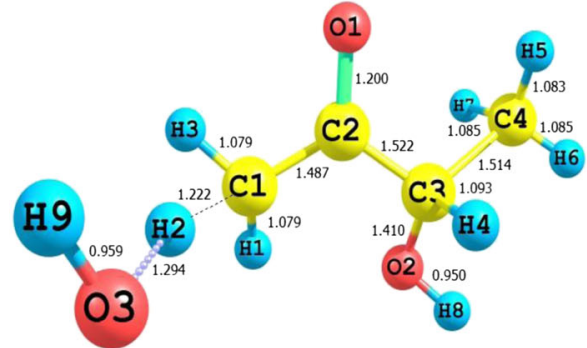

TS1a

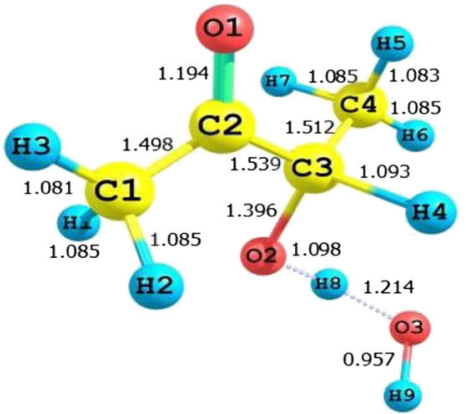

TS3

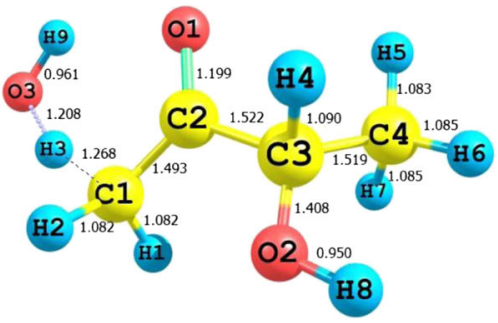

TS1b

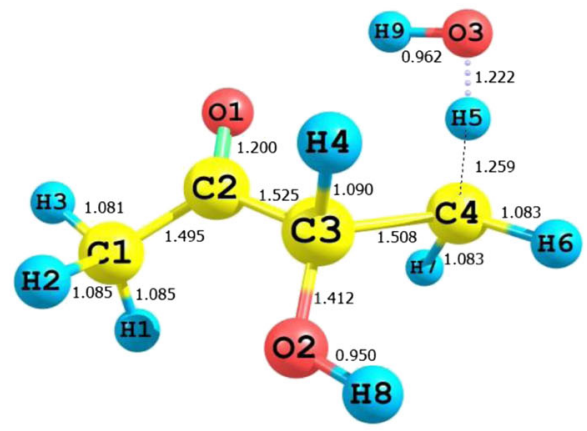

TS4b

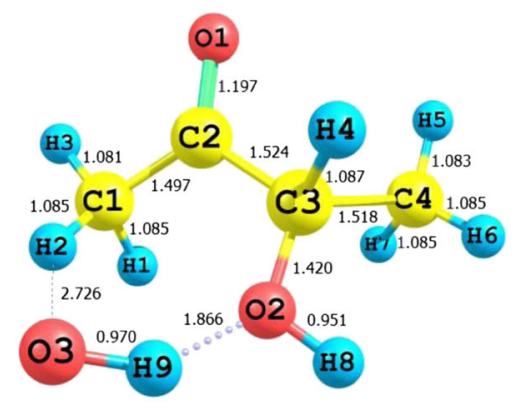

RC1a

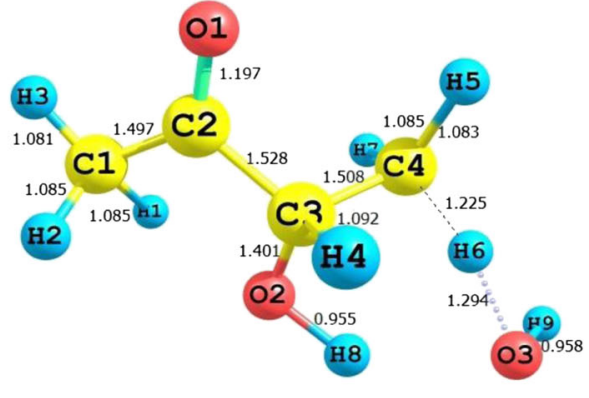

TS4a

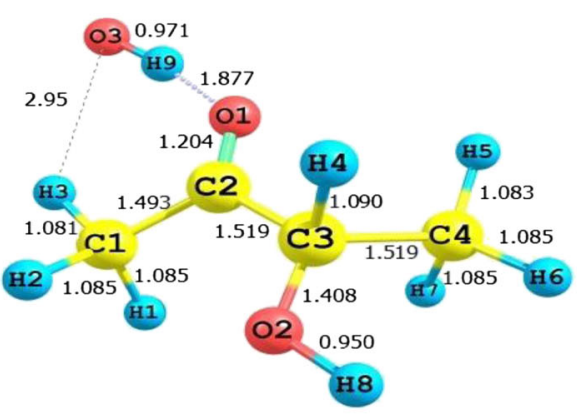

RC1b

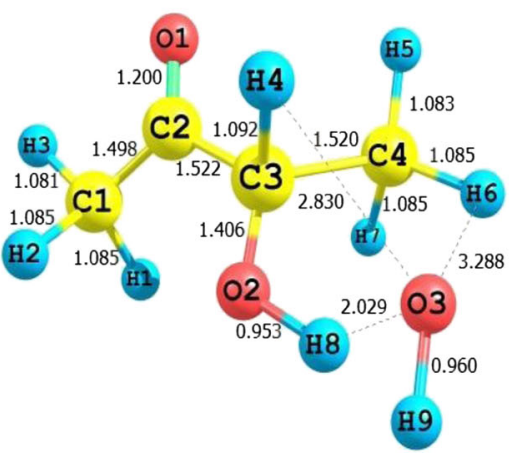

RC3/RC4a

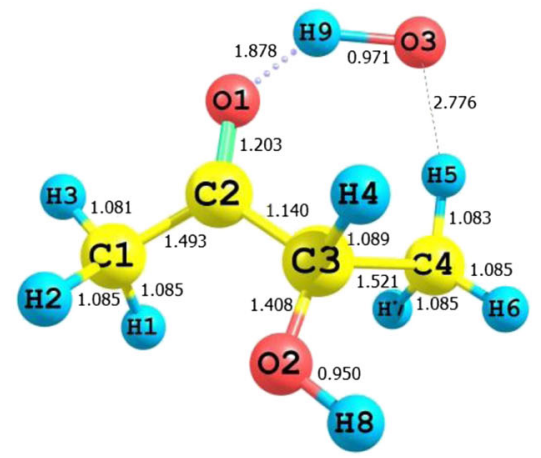

RC4b

Figure 1. Optimized geometries of reactants, reactant complexes, transition states, product complexes and products involved in the $\mathrm{H}$ atom abstraction reactions of 3H2B with $\mathrm{OH}$ radicals at BHandHLYP/6-311++G(d,p) level. Bond lengths are given in $\AA$. 


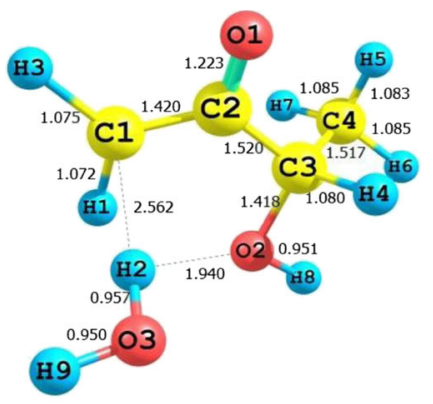

PC1a

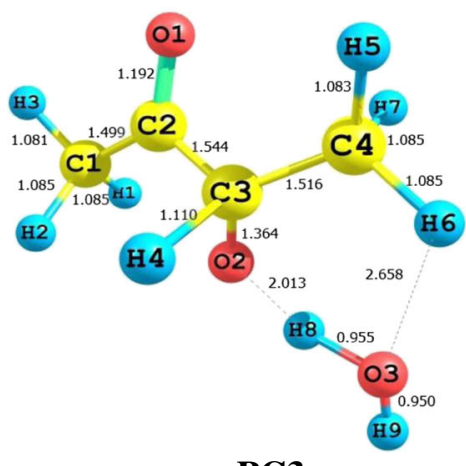

PC3

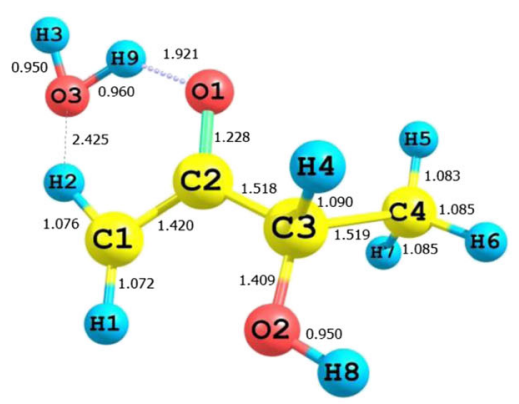

PC1b

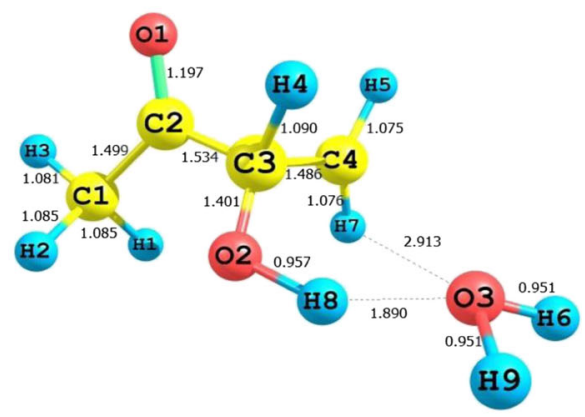

PC4a

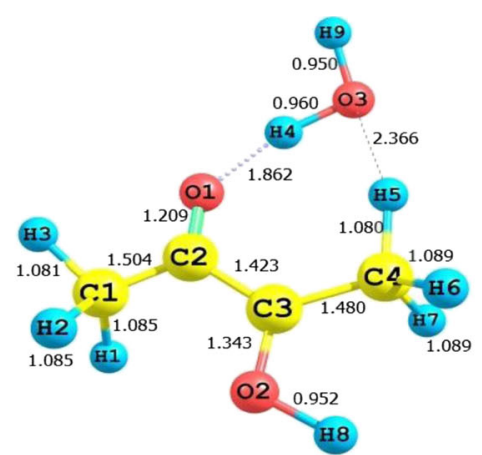

PC2

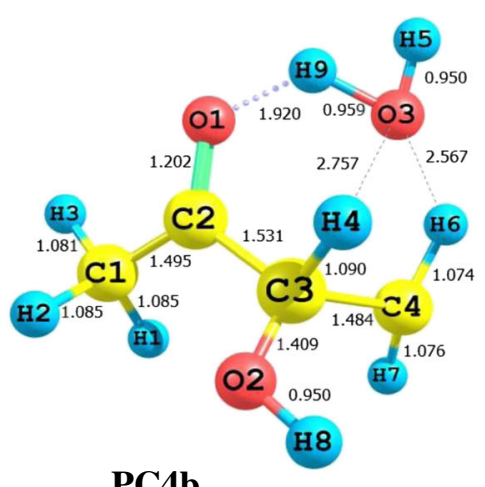

PC4b
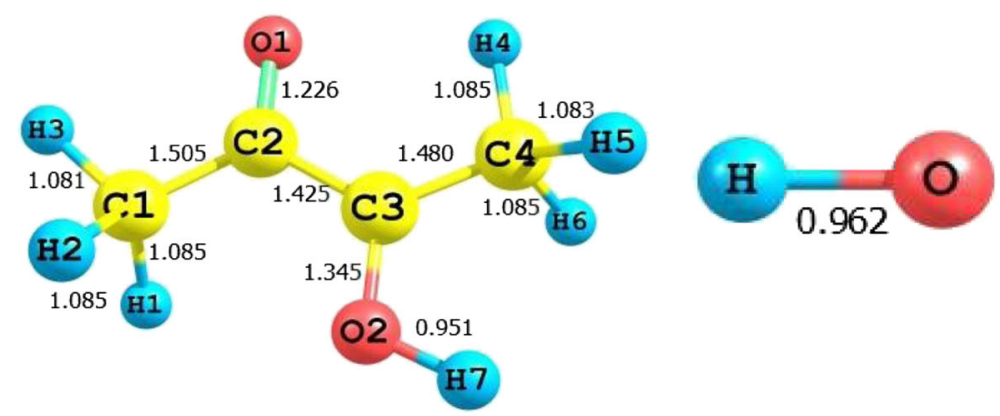

$\mathrm{CH}_{3} \mathrm{COC}(\mathrm{OH}) \mathrm{CH}_{3}(\mathrm{P} 2)$
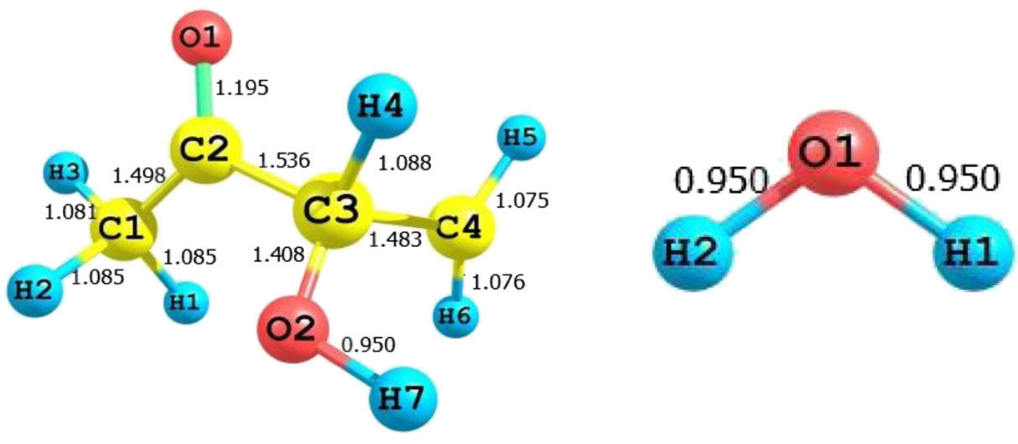

$\mathrm{CH}_{3} \mathrm{COCH}(\mathrm{O}) \mathrm{CH}_{3}(\mathrm{P3})$

\section{$\mathrm{CH}_{3} \mathrm{COCH}(\mathrm{OH}) \mathrm{CH}_{2}(\mathrm{P4})$}

Figure 1. (continued).

confirmation of the existence of transition states connecting reactants and products.

Single point energy calculations of various species involved in the hydrogen abstraction reactions were further refined by using $\operatorname{CCSD}(\mathrm{T}) / 6-311++\mathrm{G}(\mathrm{d}, \mathrm{p})$ level of theory at BHandHLYP/6-311++G(d,p) optimized geometries. Calculated total energies are corrected for zero-point energy obtained at BHandHLYP/6- 
Table 2. Harmonic vibrational frequencies of reactant, reactant complexes, transition states, product complexes and products calculated at BHandHLYP/6-311++G (d,p) level of theory.

\begin{tabular}{|c|c|}
\hline Species & Vibrational frequency $\left(\mathrm{cm}^{-1}\right)$ \\
\hline $\mathrm{CH}_{3} \mathrm{COCH}(\mathrm{OH}) \mathrm{CH}_{3}$ & $\begin{array}{l}21,158,245,258,265,318,424,499,550,626,768,940,1009,1022, \\
1093,1168,1199,1237,1305,1402,1444,1456,1463,1511,1517,1544, \\
1552,1885,3092,3114,3130,3180,3192,3215,3237,4016\end{array}$ \\
\hline $\mathrm{RC} 1 \mathrm{a}$ & $\begin{array}{l}29,35,62,171,188,248,258,269,311,415,459,510,552,620,664, \\
773,940,1008,1032,1089,1163,1185,1257,1318,1403,1446,1455, \\
1461,1513,1525,1546,1552,1888,3112,3125,3126,3179,3189, \\
3216,3236,3725,4002\end{array}$ \\
\hline $\mathrm{RC} 1 \mathrm{~b}$ & $\begin{array}{l}21,35,42,158,159,242,260,273,317,425,478,506,608,631,775, \\
941,1010,1027,1095,1168,1203,1243,1313,1399,1448,1458,1467, \\
1511,1515,1544,1552,1862,3094,3117,3130,3183,3192,3216, \\
3239,3711,4016\end{array}$ \\
\hline $\mathrm{RC} 2$ & $\begin{array}{l}29,49,61,159,172,240,258,267,315,419,455,522,549,601,630, \\
777,943,1007,1032,1092,1167,1202,1241,1318,1401,1449,1460 \text {, } \\
1467,1508,1517,1547,1549,1865,3103,3115,3132,3181,3193, \\
3214,3241,3720,4015\end{array}$ \\
\hline $\mathrm{RC} 3 / \mathrm{RC} 4 \mathrm{a}$ & $\begin{array}{l}20,30,34,100,124,160,240,247,269,327,421,450,509,553,626, \\
772,941,1008,1024,1103,1168,1204,1273,1315,1401,1445,1454, \\
1476,1511,1517,1546,1553,1882,3086,3116,3130,3182,3192, \\
3212,3235,3878,3952\end{array}$ \\
\hline $\mathrm{RC} 4 \mathrm{~b}$ & $\begin{array}{l}28,48,60,159,171,240,258,266,314,418,454,454,522,548,601, \\
630,777,943,1006,1032,1091,1166,1201,1240,1318,1400,1448, \\
1460,1467,1507,1516,1546,1548,1865,3103,3114,3131,3193, \\
3214,3241,3720,4014\end{array}$ \\
\hline
\end{tabular}

TS1a

1705i, 33, 38, 87, 170, 230, 233, 277, 343, 387, 434, 480, 552 ,637, 703, 782, 913, 943, 971, 1041, 1087, 1166, 1200, 1241, 1278, 1302, 1403, 1409, 1464, 1469, 1498, 1540, 1551, 1853, 3072, 3121, 3188, 3197 , $3219,3290,3918,4019$

TS1b

2047i, 15, 39, 134, 232, 242, 257, 280, 327, 422, 424, 479, 553, 615, 683, 763, 877, 940, 999, 1056, 1101, 1151, 1197, 1205, 1239, 1305, 1400, 1451, 1459, 1472, 1538, 1544, 1550, 1865, 3095, 3116, 3175, $3183,3215,3247,3884,4014$,

TS2

1086i, 20, 79, 117, 148, 235, 254, 289, 307, 330, 434, 489, 533, 618, 669, 757, 897, 962, 1021, 1028, 1102, 1159, 1228, 1247, 1298, 1405, $1450,1457,1497,1510,1517,1537,1548,1869,3113,3130,3178$, $3192,3224,3239,3898,4002$,

TS3

2519i, 36, 50, 127, 155, 221, 224, 241, 310, 411, 437, 508, 552, 637, $755,814,938,1003,1005,1113,1169,1185,1248,1275,1353,1402$, $1435,1448,1466,1510,1520,1542,1547,1895,3061,3127,3130,3190$, $3201,3223,3236,3946$

TS4a

$1654 \mathrm{i}, 15,73,117,156,222,226,311,408,427,494,537,547,625$, 701, 752, 848, 943, 1019, 1054, 1154, 1192, 1219, 1266, 1310, 1328, 1407, 1418, 1447, 1486, 1502, 1512, 1517, 1880, 3085, 3131, 3171, $3194,3237,3261,3930,3937$

TS4b

2027i, 24, 88, 153, 163, 254, 266, 316, 379, 428, 480, 494, 547, 633, $668,767,857,991,1015,1059,1102,1147,1192,1240,1246,1293$, $1399,1445,1472,1503,1509,1515,1518,1874,3085,3131,3159$, $3193,3240,3242,3858,4012$ 
Table 2. (continued)

\begin{tabular}{|c|c|}
\hline Species & Vibrational frequency $\left(\mathrm{cm}^{-1}\right)$ \\
\hline PC1a & $\begin{array}{l}24,27,53,95,159,221,250,261,327,411,442,445,514,552,608, \\
656,796,848,951,1040,1080,1140,1191,1262,1339,1410,1458, \\
1459,1505,1545,1550,1614,1674,3112,3124,3180,3213,3250, \\
3374,3883,3999,4060\end{array}$ \\
\hline PC1b & $\begin{array}{l}40,51,82,98,156,248,254,277,334,396,421,451,526,557,584 \\
666,803,877,952,1056,1079,1145,1202,1250,1345,1407,1458 \\
1467,1520,1544,1550,1623,1680,3099,3114,3181,3213,3245 \\
3375,3840,4016,4056\end{array}$ \\
\hline PC2 & $\begin{array}{l}29,77,92,96,109,126,172,263,335,372,373,393,514,576,587, \\
606,748,980,1044,1054,1078,1133,1279,1392,1450,1471,1509, \\
1520,1526,1536,1594,1672,1689,3085,3128,3129,3187,3234, \\
3248,3831,3997,4060\end{array}$ \\
\hline PC3 & $\begin{array}{l}20,51,58,108,127,145,207,262,316,332,398,446,491,542,635, \\
740,940,946,1001,1085,1143,1153,1200,1253,1319,1449,1468, \\
1510,1521,1540,1545,1667,1898,2964,3128,3135,3190,3209, \\
3229,3237,3919,4064\end{array}$ \\
\hline $\mathrm{PC} 4 \mathrm{a}$ & $\begin{array}{l}32,38,60,89,135,142,153,218,224,240,306,418,517,558,565 \\
632,695,803,930,1029,1059,1139,1190,1249,1315,1378,1445 \\
1464,1488,1512,1518,1671,1880,3096,3131,3196,3228,3233 \\
3346,3876,3980,4083\end{array}$ \\
\hline $\mathrm{PC} 4 \mathrm{~b}$ & $\begin{array}{l}42,68,95,138,142,166,237,254,293,310,389,417,532,558,567, \\
604,638,798,943,1026,1057,1140,1181,1231,1322,1366,1433, \\
1448,1508,1517,1680,1861,3122,3132,3196,3226,3237,3354, \\
3841,4006,4058\end{array}$ \\
\hline $\mathrm{CH}_{2} \mathrm{COCH}(\mathrm{OH}) \mathrm{CH}_{3}$ & $\begin{array}{l}51,245,259,266,334,415,445,510,549,656,792,850,951,1045 \\
1077,1146,1200,1245,1331,1409,1458,1464,1505,1544,1550 \\
1617,3099,3113,3179,3212,3250,3377,4017\end{array}$ \\
\hline $\mathrm{CH}_{3} \mathrm{COC}(\mathrm{OH}) \mathrm{CH}_{3}$ & $\begin{array}{l}88,127,129,255,319,340,374,503,578,591,741,975,1038,1053, \\
1077,1131,1273,1392,1448,1460,1504,1520,1526,1535,1583, \\
1670,3084,3125,3127,3184,3231,3235,4001\end{array}$ \\
\hline $\mathrm{CH}_{3} \mathrm{COCH}(\mathrm{O}) \mathrm{CH}_{3}$ & $\begin{array}{l}54,146,201,253,311,401,471,531,626,726,912,947,996,1066, \\
1138,1150,1198,1251,1346,1450,1462,1510,1521,1536,1542 \\
1896,2971,3128,3134,3191,3206,3222,3236\end{array}$ \\
\hline $\mathrm{CH}_{3} \mathrm{COCH}(\mathrm{OH}) \mathrm{CH}_{2}$ & $\begin{array}{l}65,142,214,231,287,307,412,521,561,568,635,796,931,1023, \\
1058,1138,1181,1223,1311,1362,1427,1447,1493,1512,1519 \\
1886,3111,3131,3195,3229,3235,3348,4006\end{array}$ \\
\hline $\mathrm{H}_{2} \mathrm{O}$ & $1652,3983,4087$ \\
\hline $\mathrm{OH}$ & 3884 \\
\hline
\end{tabular}

$311 \mathrm{G}++(\mathrm{d}, \mathrm{p})$ level. The associated energy barrier with zero-point energy correction for various species and transition states involved in the title reactions calculated at $\operatorname{CCSD}(\mathrm{T}) / 6-311++\mathrm{G}(\mathrm{d}, \mathrm{p})$ and BHandHLYP/6$311++\mathrm{G}(\mathrm{d}, \mathrm{p})$ methods are recorded in table 3 . The results show that the calculation performed during the present study utilizing $\operatorname{CCSD}(\mathrm{T})$ yields the barrier height of $4.73,4.80,-1.09,4.49,3.03$ and $3.39 \mathrm{kcal}$ $\mathrm{mol}^{-1}$, respectively for reactions (R1-R4) whereas these values are $6.23,6.61,0.55,6.28,4.66$ and
$5.11 \mathrm{kcal} \mathrm{mol}^{-1}$, respectively for TS1a, TS1b, TS2, TS3, TS4a and TS4b at BHandHLYP level. A schematic potential energy surface of the $3 \mathrm{H} 2 \mathrm{~B}+\mathrm{OH}$ reactions are plotted and shown in figure 2 . In the construction of energy diagram, relative energy including zero-point correction as recorded in table 3 are utilized. Literature survey reveals that there is no experimental data available for the comparison of the energy barrier for the $\mathrm{H}$-atom abstraction reaction of $3 \mathrm{H} 2 \mathrm{~B}$ by $\mathrm{OH}$ radicals. However, our calculated barrier heights are 
in reasonable agreement with the previous studies on hydrogen abstraction reactions of similar hydroxyacetone $\left(\mathrm{CH}_{3} \mathrm{C}(\mathrm{O}) \mathrm{CH}_{2} \mathrm{OH}\right)$ with $\mathrm{OH}$ radicals by Galano et al. ${ }^{15}$ Dillon et al. ${ }^{16}$ and Baasandorj et al. ${ }^{17}$ The reaction of hydroxyacetone with the $\mathrm{OH}$ radical is thought to proceed mainly by abstraction of a secondary $\mathrm{H}$-atom from $-\mathrm{CH}_{2}(\mathrm{OH})$ site. ${ }^{15-17}$ Our calculation also confirms that the hydrogen abstraction from the $-\mathrm{CH}$ group attached to hydroxyl group is more facile than that from the other reaction channels. This finding is in line with the observation made in an earlier report, ${ }^{23}$ as well as to the fact that the calculated $\mathrm{C}-\mathrm{H}$ bond dissociation energy from $-\mathrm{CH}$ group $\left(90.52 \mathrm{kcal} \mathrm{mol}^{-1}\right)$ is much lower than that for the other sites (cf. table 5). The thermodynamic parameters also reveal that $\mathrm{H}$-abstraction from $-\mathrm{CH}$ group is kinetically more favourable than that of the other reaction channels. Moreover, spin contamination is not important for the $3 \mathrm{H} 2 \mathrm{~B}+\mathrm{OH}$ reactions because $<\mathrm{S}^{2}>$ is found to be 0.76 at BHandHLYP/6-311G++ $(\mathrm{d}, \mathrm{p})$ before annihilation that is only slightly larger than the expected value of $\left.<S^{2}\right\rangle=0.75$ for doublets.

The standard enthalpy of formation $\left(\Delta_{\mathrm{f}} \mathrm{H}_{298}^{\circ}\right)$ at $298 \mathrm{~K}$ for $3 \mathrm{H} 2 \mathrm{~B}$ and the radicals generated from hydrogen abstraction, $\mathrm{CH}_{2} \mathrm{COCH}(\mathrm{OH}) \mathrm{CH}_{3}(\mathrm{P} 1)$, $\mathrm{CH}_{3} \mathrm{COC}(\mathrm{OH}) \mathrm{CH}_{3}(\mathrm{P} 2) \mathrm{CH}_{3} \mathrm{COCH}(\mathrm{O}) \mathrm{CH}_{3}(\mathrm{P} 3)$ and $\mathrm{CH}_{3} \mathrm{COCH}(\mathrm{OH}) \mathrm{CH}_{3}(\mathrm{P} 4)$ can be valuable information for understanding the mechanism and thermochemical properties of their reactions and most importantly for atmospheric modeling, but these values are not yet reported. The group-balanced isodesmic reactions, in which the number and types of bonds are conserved, are used as working chemical reactions herein to calculate the $\Delta_{\mathrm{f}} \mathrm{H}_{298}^{\circ}$. Here, four isodesmic reactions are used to estimate the enthalpies of formation of the $\mathrm{CH}_{3} \mathrm{COCH}(\mathrm{OH}) \mathrm{CH}_{3}$. The used isodesmic reactions are as follows:

$$
\begin{array}{llll}
\mathrm{CH}_{3} \mathrm{COCH}(\mathrm{OH}) \mathrm{CH}_{3}+\mathrm{CH}_{4} & \rightarrow & \mathrm{CH}_{3} \mathrm{COCH}_{3}+\mathrm{CH}_{3} \mathrm{CH}_{2} \mathrm{OH} \\
\mathrm{CH}_{3} \mathrm{COCH}(\mathrm{OH}) \mathrm{CH}_{3}+\mathrm{CHF}_{3} & \rightarrow & \mathrm{CH}_{3} \mathrm{C}(\mathrm{O}) \mathrm{OH}+\mathrm{CF}_{3} \mathrm{CH}_{2} \mathrm{CH}_{3} \\
\mathrm{CH}_{3} \mathrm{COCH}(\mathrm{OH}) \mathrm{CH}_{3}+\mathrm{CH}_{3} & \rightarrow & \mathrm{CH}_{2} \mathrm{C}(\mathrm{O}) \mathrm{CH}_{2} \mathrm{CH}_{3}+\mathrm{CH}_{3} \mathrm{OH} \\
\mathrm{CH}_{3} \mathrm{COCH}(\mathrm{OH}) \mathrm{CH}_{3}+\mathrm{CH}_{3} \mathrm{CH}_{3} & \rightarrow & \mathrm{CH}_{3} \mathrm{C}(\mathrm{O}) \mathrm{CH}_{2} \mathrm{CH}_{3}+\mathrm{CH}_{3} \mathrm{CH}_{2} \mathrm{OH}
\end{array}
$$

Table 3. Zero-point energy corrected associated energy barriers, $\Delta \mathrm{E}$ in $\mathrm{kcal} \mathrm{mol}^{-1}$ of reactant, reactant complexes, transition states, product complexes and products at CCSD (T)/6-311++G(d,p) and BHandHLYP/6-311++G(d,p) levels of theory.

\begin{tabular}{lrr}
\hline Species & CCSD(T) & BHandHLYP \\
\hline $\mathrm{CH}_{3} \mathrm{COCH}(\mathrm{OH}) \mathrm{CH}_{3}+\mathrm{OH}$ & 0.00 & 0.00 \\
$\mathrm{RC1a}$ & -3.12 & -4.12 \\
$\mathrm{RC} 1 \mathrm{~b}$ & -3.32 & -5.54 \\
$\mathrm{RC} 2$ & -3.50 & -5.50 \\
& & \\
$\mathrm{RC} 3 / \mathrm{RC} 4 \mathrm{a}$ & -2.10 & -3.16 \\
$\mathrm{RC} 4 \mathrm{~b}$ & -3.80 & -4.70 \\
$\mathrm{TS} 1 \mathrm{a}$ & 4.73 & 6.23 \\
$\mathrm{TS} 1 \mathrm{~b}$ & 4.80 & 6.60 \\
$\mathrm{TS} 2$ & -1.09 & 0.55 \\
$\mathrm{TS3}$ & 4.49 & 6.28 \\
$\mathrm{TS} 4 \mathrm{a}$ & 3.03 & 4.66 \\
$\mathrm{TS} 4 \mathrm{~b}$ & 3.39 & 5.11 \\
$\mathrm{PC} 1 \mathrm{a}$ & -22.20 & -21.98 \\
$\mathrm{PC} 1 \mathrm{~b}$ & -23.30 & -23.89 \\
$\mathrm{PC} 2$ & -36.48 & -38.77 \\
$\mathrm{PC} 3$ & -14.20 & -15.18 \\
$\mathrm{PC} 4 \mathrm{a}$ & -18.79 & -17.29 \\
$\mathrm{PC} 4 \mathrm{~b}$ & -19.01 & -17.47 \\
$\mathrm{CH}_{2} \mathrm{COCH}(\mathrm{OH}) \mathrm{CH}_{3}(\mathbf{P 1})+\mathrm{H}_{2} \mathrm{O}$ & -18.46 & -18.93 \\
$\left.\mathrm{CH} \mathrm{COC}_{3} \mathrm{OH}\right) \mathrm{CH}_{3}(\mathbf{P 2})+\mathrm{H}_{2} \mathrm{O}$ & -30.83 & -33.08 \\
$\left.\mathrm{CH} \mathrm{COCH}_{3} \mathrm{O}\right) \mathrm{CH}_{3}(\mathbf{P 3})+\mathrm{H}_{2} \mathrm{O}$ & -10.94 & -12.32 \\
$\mathrm{CH} \mathrm{COCH}_{3}(\mathrm{OH}) \mathrm{CH}_{2}(\mathbf{P 4})+\mathrm{H}_{2} \mathrm{O}$ & -13.33 & -12.07 \\
\hline
\end{tabular}

All geometrical parameters of the species involved in the isodesmic reactions (R5-R8) were first optimized at the BHandHLYP/6-311++G(d,p) level and then energies of the species were further refined by performing single-point calculations at the sophisticated $\operatorname{CCSD}(\mathrm{T})$ level of theory. At first, we have calculated the reaction enthalpies $\left(\Delta_{\mathrm{r}} \mathrm{H}_{298}^{\circ}\right)$ of the isodesmic reactions (R5-R8) as mentioned above, using total energies of the species obtained at $\operatorname{CCSD}(\mathrm{T}) / 6-311++\mathrm{G}(\mathrm{d}, \mathrm{p})$ level and including thermal correction to enthalpy estimated at BHandHLYP/6-311++G(d,p) level. Since, the $\left(\Delta_{\mathrm{r}} \mathrm{H}_{298}^{\circ}\right)$ value corresponds to the difference of the enthalpy of formation $\left(\Delta_{\mathrm{f}} \mathrm{H}_{298}^{\circ}\right)$ values between the products and the reactants, the $\left(\Delta_{\mathrm{f}} \mathrm{H}_{298}^{\circ}\right)$ values of the reactant and product species are easily evaluated by combining them with the known enthalpies of formation of the reference compounds involved in our isodesmic reaction schemes. The experimental $\Delta_{\mathrm{f}} \mathrm{H}_{298}^{\circ}$ values for $\mathrm{CH}_{4}$ : $-17.89 \mathrm{kcal} \mathrm{mol}{ }^{-1}, \mathrm{CH}_{3} \mathrm{COCH}_{3}$ : $-51.9 \mathrm{kcal} \mathrm{mol}^{-1}, \mathrm{CH}_{3} \mathrm{CH}_{2} \mathrm{OH}:-56.23 \mathrm{kcal} \mathrm{mol}^{-1}$, $\mathrm{CH}_{3} \mathrm{CH}_{3:}-20.24 \mathrm{kcal} \mathrm{mol}^{-1}, \mathrm{CH}_{3:} 34.82 \mathrm{kcal} \mathrm{mol}^{-1}$ $\mathrm{CH}_{2} \mathrm{C}(\mathrm{O}) \mathrm{CH}_{2} \mathrm{CH}_{3}$ : $-13.57 \mathrm{kcal} \mathrm{mol}^{-1}, \mathrm{CH}_{3} \mathrm{C}(\mathrm{O}) \mathrm{CH}_{2}$ $\mathrm{CH}_{3}$ : $-57.02 \mathrm{kcal} \mathrm{mol}^{-1}, \mathrm{CH}_{3} \mathrm{OH}:-48.08 \mathrm{kcal} \mathrm{mol}^{-1}$ are taken from Ref. ${ }^{2}, \mathrm{CHF}_{3:}-166.60 \mathrm{kcal} \mathrm{mol}^{39}$, $\mathrm{CH}_{3} \mathrm{C}(\mathrm{O}) \mathrm{OH}:-103.44 \mathrm{kcal} \mathrm{mol}^{40}, \mathrm{CF}_{3} \mathrm{CH}_{2} \mathrm{CH}_{3}$ : $-183.09 \mathrm{kcal} \mathrm{mol}^{41}$ to evaluate the required enthalpies 


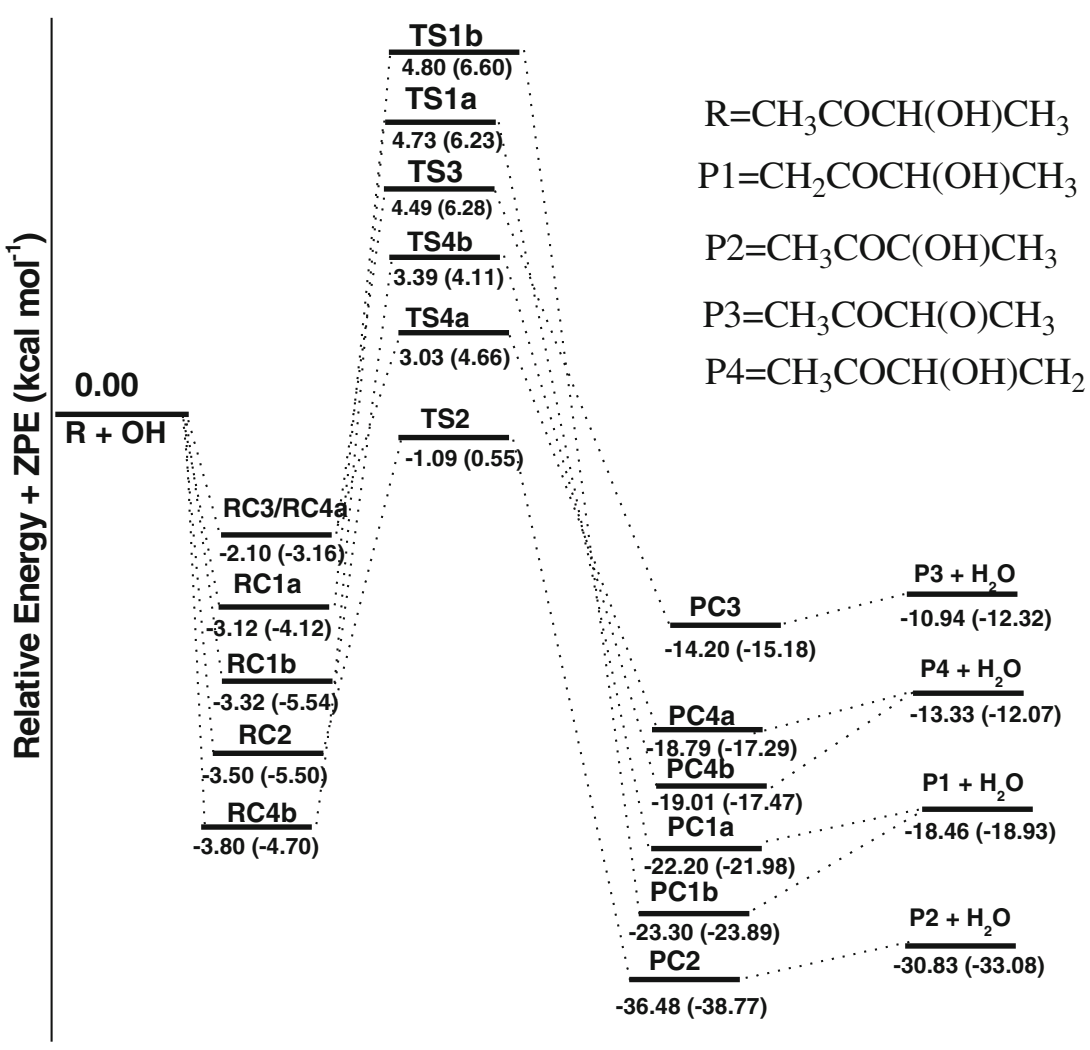

Figure 2. Schematic potential energy profiles (including $\mathrm{ZPE}$ ) for the $3 \mathrm{H} 2 \mathrm{~B}$ $+\mathrm{OH}$ reactions at the $\mathrm{CCSD}(\mathrm{T}) / 6-311++\mathrm{G}(\mathrm{d}, \mathrm{p})$ level. The values given in parentheses are calculated at BHandHLYP/6-311++G(d,p) + ZPE level of theory.

of formation. The calculated values of enthalpies of formation are listed in table 4 . The $\Delta_{\mathrm{f}} \mathrm{H}_{298}^{\circ}$ for $3 \mathrm{H} 2 \mathrm{~B}$ calculated from $\operatorname{CCSD}(\mathrm{T})$ and BHandHLYP results are -96.23 and $-93.23 \mathrm{kcal} \mathrm{mol}^{-1}$, respectively. The $\Delta_{\mathrm{f}} \mathrm{H}_{298}^{\circ}$ values for radicals generated by hydrogen abstraction (P1, P2, P3 and P4) can also be easily calculated from the reported $\Delta_{\mathrm{r}} \mathrm{H}_{298}^{\circ}$ values for reactions $\mathrm{R} 1-\mathrm{R} 4$ in table 1 , the calculated $\Delta_{\mathrm{f}} \mathrm{H}_{298}^{\circ}$ value for $3 \mathrm{H} 2 \mathrm{~B}$ and the experimental $\Delta_{\mathrm{f}} \mathrm{H}_{298}^{\circ}$ values for $\mathrm{H}_{2} \mathrm{O}(-57.8$

Table 4. Enthalpies of formation $\left(\Delta_{\mathrm{f}} \mathrm{H}_{298}^{0}\right)\left(\mathrm{kcal} \mathrm{mol}^{-1}\right)$ for species at CCSD(T) and BHandHLYP/6-311++G(d,p) levels of theory.

\begin{tabular}{|c|c|c|c|}
\hline Species & $\begin{array}{l}\text { Isodesmic } \\
\text { Reaction } \\
\text { Schemes }\end{array}$ & CCSDT & BHandHLYP \\
\hline \multirow[t]{4}{*}{$3 \mathrm{H} 2 \mathrm{~B}$} & R5 & -96.03 & -93.29 \\
\hline & R6 & -94.96 & -91.91 \\
\hline & $\mathrm{R} 7$ & -98.06 & -93.70 \\
\hline & $\mathrm{R} 8$ & -96.05 & -94.14 \\
\hline Average & & -96.27 & -93.26 \\
\hline $\mathrm{CH}_{2} \mathrm{COCH}(\mathrm{OH}) \mathrm{CH}_{3}(\mathbf{P 1})$ & & -45.79 & -45.46 \\
\hline $\mathrm{CH}_{3} \mathrm{COC}(\mathrm{OH}) \mathrm{CH}_{3}(\mathbf{P 2})$ & & -57.85 & -59.30 \\
\hline $\mathrm{CH}_{3} \mathrm{COCH}(\mathrm{O}) \mathrm{CH}_{3}(\mathbf{P 3})$ & & -38.19 & -38.77 \\
\hline $\mathrm{CH}_{3} \mathrm{COCH}(\mathrm{OH}) \mathrm{CH}_{2}(\mathbf{P 4})$ & & -40.29 & -38.23 \\
\hline
\end{tabular}

kcal $\left.\mathrm{mol}^{-1}\right)$ and $\mathrm{OH}\left(8.93 \mathrm{kcal} \mathrm{mol}^{-1}\right) \mathrm{radical}^{2}$. The $\Delta_{\mathrm{f}} \mathrm{H}_{298}^{\circ}$ values for $\mathrm{P} 1, \mathrm{P} 2, \mathrm{P} 3$ and $\mathrm{P} 4$ radicals calculated from the $\operatorname{CCSD}(\mathrm{T})$ results are -45.79 , $-57.85,-38.19$ and $-40.29 \mathrm{kcal} \mathrm{mol}^{-1}$, respectively; whereas for the same BHandHLYP results amount to $-45.46,-59.30,-38.77$ and $-38.23 \mathrm{kcal} \mathrm{mol}^{-1}$, respectively. Moreover, because of the lack of experimental values for the $\Delta_{\mathrm{f}} \mathrm{H}_{298}^{\circ}$ of the species involved in the title reactions, it is difficult to make a direct comparison between theoretical and experimental enthalpy of formation. Since, these data are not available in the literature and can therefore be useful for further thermochemical and kinetic modeling of reaction involving these species.

The calculated bond-dissociation energies, BDE $\left(\mathrm{D}_{298}^{0}\right)$ of the $\mathrm{C}-\mathrm{H}$ bonds of $\mathrm{CH}_{3} \mathrm{COCH}(\mathrm{OH}) \mathrm{CH}_{3}$ molecule are recorded in table 5 . The $\mathrm{D}_{298}^{0}$ value obtained from the $\operatorname{CCSD}(\mathrm{T})$ results for the $\mathrm{C}-\mathrm{H}$ bonds in the $-\mathrm{CH}_{3} \mathrm{C}(\mathrm{O}),-\mathrm{CH}$ (attached to hydroxyl group), $-\mathrm{OH}$ and $-\mathrm{CH}_{3}$ sites of $3 \mathrm{H} 2 \mathrm{~B}$ amount to $102.58,90.52$, 110.18 and $108.08 \mathrm{kcal} \mathrm{mol}^{-1}$, respectively. The $\mathrm{D}_{298}^{0}$ values obtained from BHandHLYP/6-311++G(d,p) results amount to be $99.90,86.07,106.59$ and 107.13 $\mathrm{kcal} \mathrm{mol}^{-1}$, respectively. No comparison between theory and experiment can be made due to the lack of the 
Table 5. Calculated bond dissociation energy $\left(\mathrm{D}_{298}^{0}\right)\left(\mathrm{kcal} \mathrm{mol}^{-1}\right)$ for species at $298 \mathrm{~K}$ at CCSD(T) /6-311++G(d,p) and BHandHLYP/6-311++G(d,p) levels of theory.

\begin{tabular}{lrr}
\hline Bond dissociation type & CCSD $(\mathrm{T})$ & BHandHLYP \\
\hline $\mathrm{C}-\mathrm{H}$ bond & & \\
$\mathrm{CH}_{3} \mathrm{COCH}(\mathrm{OH}) \mathrm{CH}_{3} \rightarrow \mathrm{CH}_{2} \mathrm{COCH}(\mathrm{OH}) \mathrm{CH}_{3}+\mathrm{H}$ & 102.58 & 99.90 \\
$\mathrm{CH}_{3} \mathrm{COCH}(\mathrm{OH}) \mathrm{CH}_{3} \rightarrow \mathrm{CH}_{3} \mathrm{COC}(\mathrm{OH}) \mathrm{CH}_{3}+\mathrm{H}$ & 90.52 & 86.07 \\
$\mathrm{CH}_{3} \mathrm{COCH}(\mathrm{OH}) \mathrm{CH}_{3} \rightarrow \mathrm{CH}_{3} \mathrm{COCH}(\mathrm{O}) \mathrm{CH}_{3}+\mathrm{H}$ & 110.18 & 106.59 \\
$\mathrm{CH}_{3} \mathrm{COCH}(\mathrm{OH}) \mathrm{CH}_{3} \rightarrow \mathrm{CH}_{3} \mathrm{COCH}(\mathrm{OH}) \mathrm{CH}_{2}+\mathrm{H}$ & 108.08 & 107.13 \\
\hline
\end{tabular}

experimental $\mathrm{D}_{298}^{0}$ values. However, our calculated $\mathrm{D}_{298}^{0}$ value for the four $\mathrm{C}$-H bonds of 3-hydroxy-2-butanone is in reasonable agreement with calculated $\mathrm{D}_{298}^{0}$ values for the $\mathrm{C}-\mathrm{H}$ bonds in a similar ketone (3-methyl2-butanone) reported by Hudzik and Bozzelli. ${ }^{42}$ Moreover, owing to the lower $\mathrm{C}-\mathrm{H}$ bond dissociation energy; $\mathrm{CH}$ site attached to hydroxyl group is more reactive toward hydrogen abstraction than other sites. This is reflected in the calculated barrier height for hydrogen abstraction from $-\mathrm{CH}_{3} \mathrm{C}(\mathrm{O}), \mathrm{CH}$ (attached to hydroxyl group) $-\mathrm{OH}$ and $-\mathrm{CH}_{3}$ groups.

\subsection{Rate constants}

The rate constant for reactions channels (R1-R4) are calculated by using Canonical Transition State Theory ${ }^{43}$ given by the following expression:

$$
\mathrm{k}=\sigma \Gamma(\mathrm{T}) \frac{\mathrm{k}_{\mathrm{B}} \mathrm{T}}{\mathrm{h}} \frac{\mathrm{Q}_{\mathrm{TS}}}{\mathrm{Q}_{\mathrm{A}} \cdot \mathrm{Q}_{\mathrm{B}}} \exp \frac{-\Delta \mathrm{E}^{\#}}{\mathrm{RT}}
$$

Where, $\sigma$ is the number of equivalent $\mathrm{H}$-atoms, $\Gamma(\mathrm{T})$ is the tunneling correction factor at temperature $\mathrm{T}$. $\mathrm{Q}_{\mathrm{TS}}$, $\mathrm{Q}_{\mathrm{A}}$ and $\mathrm{Q}_{\mathrm{B}}$ are the total partition functions (per unit volume) for the transition states and reactants, respectively. $\Delta \mathrm{E}^{\#}$ is the barrier height including zero point energy correction, $\mathrm{k}_{\mathrm{B}}$ is the Boltzmann constant, $\mathrm{h}$ is the Planck's constant and $\mathrm{R}$ represents the universal gas constant. The tunneling correction was estimated by using the Eckart's unsymmetrical barrier method. ${ }^{44}$ All vibrational modes, except the lowest vibrational mode, were treated quantum mechanically as separable harmonic oscillators, whereas for the lowest-frequency mode, the partition function was evaluated by the hindered-rotor approximation by Truhlar and Chuang ${ }^{45}$ method. Using Truhlar's procedure ${ }^{46}$ the $\mathrm{q}^{\mathrm{HIN}} / \mathrm{q}^{\mathrm{HO}}$ ratio was found to be close to unity. Some of the low lying vibrational frequencies that are included in the Qvib are termed as internal rotations. In this type of rotation, one part of the molecule rotates with respect to the other part in torsion angle. Such a rotor may be treated in three different ways depending on the rotational barrier. If barrier to rotation is much lesser than the room tem- perature energy, $\mathrm{kT}$ or $207 \mathrm{~cm}^{-1}$, then the rotation is treated as a free rotor. On the other hand, if the barrier is much larger than $\mathrm{kT}$, then the rotation would be treated as harmonic oscillator or as a normal harmonic vibration. In the intermediate cases where the torsional barrier is comparable to $\mathrm{kT}$, the rotation is treated as hindered-rotor. The harmonic contribution of these internal rotations to the vibrational partition function is written as $\mathrm{Q}_{\mathrm{IR}}$. In order to consider the harmonic contribution of these internal rotations to the vibrational partition function, the harmonic contribution of the vibrations due to hindered and free rotors were eliminated from the vibrational partition function $\mathrm{Q}_{\mathrm{vib}}$ of reactants and transition states and the corrected vibrational partition function for reactants and transition states were evaluated using the following expression:

$$
Q_{\text {corr }}=\frac{Q_{H O} \cdot Q_{I R}}{\Pi_{Q v=i}}
$$

Where, $\mathrm{Q}_{\mathrm{HO}}$ is the harmonic oscillator partition function, $Q_{I R}$ the internal rotation partition function and $\mathrm{Q}_{\mathrm{v}=\mathrm{i}}$ is the partition function of normal mode vibrations corresponding to internal rotation. During the calculation of total partition function for $\mathrm{OH}$ radical, its electronic partition function was corrected by considering the excited state of $\mathrm{OH}$ radical with a $140 \mathrm{~cm}^{-1}$ splitting by using the expression given below:

$$
\mathrm{Q}^{\mathrm{E}}(\mathrm{OH})=2+2 \exp \left[-\frac{140\left(\mathrm{~cm}^{-1}\right) \mathrm{hc}_{0}}{\mathrm{k}_{\mathrm{b}} \mathrm{T}}\right]
$$

The partition functions for the respective transition states and reactants at any temperature are calculated with rigid rotor and harmonic oscillator approximations and the vibrational frequencies obtained from the BHandHLYP/6-311++G(d,p) level are used. As discussed before, the $\mathrm{H}$-abstraction by $\mathrm{OH}$ radicals proceeds via a two-step mechanism. The first step involves a fast pre-equilibrium $\left(\mathrm{K}_{\mathrm{eq}}\right)$ between the reactants and the hydrogen bonded reaction complex (RC) and the second step is the hydrogen abstraction with the rate constant $k_{2}^{\dagger}$. The overall rate constant including 
equilibrium constant $\left(\mathrm{K}_{\mathrm{eq}}\right)$ and rate constant $\left(\mathrm{k}_{2}^{\dagger}\right)$ are given by,

$$
\mathrm{K}_{\mathrm{eq}}=\frac{\mathrm{Q}_{\mathrm{RC}}}{\mathrm{Q}_{\mathrm{A}} \cdot \mathrm{Q}_{\mathrm{B}}} \mathrm{e}\left(\mathrm{E}_{\mathrm{R}}-\mathrm{E}_{\mathrm{RC}}\right) / \mathrm{RT}
$$

and $\mathrm{k}_{2}^{\dagger}$ can be obtained from Eq. 4

$$
\mathrm{k}_{2}^{\dagger}=\sigma \Gamma(\mathrm{T}) \frac{\mathrm{k}_{\mathrm{B}} \mathrm{T}}{\mathrm{h}} \frac{\mathrm{Q}_{\mathrm{TS}}}{\mathrm{Q}_{\mathrm{RC}}} \mathrm{e}^{-\left(\mathrm{E}_{\mathrm{TS}}-\mathrm{E}_{\mathrm{RC}}\right) / \mathrm{RT}}
$$

The rate constant for $\mathrm{H}$-abstraction from $3 \mathrm{H} 2 \mathrm{~B}$ via reaction (R1) is then obtained by the following expression,

$$
\mathrm{k}=\mathrm{K}_{\mathrm{eq}} \times \mathrm{k}_{2}^{\dagger}=\sigma \Gamma(\mathrm{T}) \frac{\mathrm{k}_{\mathrm{B}} \mathrm{T}}{\mathrm{h}} \frac{\mathrm{Q}_{\mathrm{TS}}}{\mathrm{Q}_{\mathrm{A}} \cdot \mathrm{Q}_{\mathrm{B}}} \mathrm{e}-\frac{\mathrm{E}_{\mathrm{TS}}-\mathrm{E}_{\mathrm{R}}}{\mathrm{RT}}
$$

where $\mathrm{Q}_{\mathrm{A}}, \mathrm{Q}_{\mathrm{B}}, \mathrm{Q}_{\mathrm{RC}}$ and $\mathrm{Q}_{\mathrm{TS}}$ represents the total partition functions (per unit volume) of the reactants, reaction complex and transition states, respectively. $\mathrm{E}_{\mathrm{TS}}, \mathrm{E}_{\mathrm{RC}}$ and $\mathrm{E}_{\mathrm{R}}$ are the total energies (ZPE corrected) of transition state, reaction complex and reactants, respectively. Thus, it seems that the final expression (Eq. 5) for estimating rate constant and barrier height turns out to be the usual CTST expression (Eq. 1) used for the determination of rate constant and barrier height of a direct reaction, irrespective of the energy of pre-reactive hydrogen bonded complex (RC). Of course, the formation of pre and post-reaction complexes modify the shape of potential energy surface for the reaction and hence affects the tunneling factor. As a result, the rate constant for hydrogen abstraction reactions also changes. In our case, the rate constant is seen to increase by 1.3 to1.6 times at $298 \mathrm{~K}$ compared to the rate constant value for direct reaction from reactants to products due to greater tunneling factor. The branching ratios for the $\mathrm{H}$-abstraction reaction channels, which represent their individual contribution towards overall reaction rate has been determined by using the following expression,

$$
\text { Branching ratio }=\frac{\mathrm{k}}{\mathrm{k}_{\text {total }}} \times 100
$$

The partial rate coefficients cannot be determined experimentally because reactions occur simultaneously, and in some cases they even lead to the same products. Thus, the experimental data are mostly available only for the overall reactions. That is why theoretical methods can be so valuable for the full understanding of the chemical systems. As stated earlier, 3H2B $+\mathrm{OH}$ reactions pass through four different channels (R1-R4) the contribution from each of these channels needs to be taken into account while calculating the total rate coefficient $\left(\mathrm{k}_{\mathrm{OH}}\right)$ for the titled reaction. The total rate coefficient $\left(\mathrm{k}_{\mathrm{OH}}\right)$ is therefore, obtained from the addition of rate coefficients for the four channels: $\mathrm{k}_{\mathrm{OH}}=$
Table 6. The total rate constant values $\mathrm{k}_{\mathrm{OH}}$ (in $\mathrm{cm}^{3}$ molecule ${ }^{-1} \mathrm{~s}^{-1}$ ) for hydrogen abstraction reactions of $3 \mathrm{H} 2 \mathrm{~B}$ with $\mathrm{OH}$ radicals using $\operatorname{CCSD}(\mathrm{T}) / 6-311++\mathrm{G}(\mathrm{d}, \mathrm{p})$ barrier heights.

\begin{tabular}{lcc}
\hline $\mathrm{T}(\mathrm{K})$ & $\mathrm{k}_{\mathrm{OH}}$ & Exp. values \\
\hline 250 & $0.856 \mathrm{E}-11$ & \\
298 & $1.20 \mathrm{E}-11$ & $1.03 \mathrm{E}-11^{\mathrm{a}} ; 0.96 \mathrm{E}-11^{\mathrm{b}}$ \\
300 & $1.22 \mathrm{E}-11$ & \\
350 & $1.54 \mathrm{E}-11$ & \\
400 & $1.91 \mathrm{E}-11$ & \\
450 & $2.25 \mathrm{E}-11$ & \\
\hline
\end{tabular}

${ }^{\mathrm{a}}$ Aschmann et al. ${ }^{14} ;{ }^{\mathrm{b}}$ Messaadia et al..$^{23}$

$(\mathrm{kR} 1 \mathrm{a}+\mathrm{kR} 1 \mathrm{~b})+\mathrm{kR} 2+\mathrm{kR} 3+(\mathrm{kR} 4 \mathrm{a}+\mathrm{kR} 4 \mathrm{~b})$. The calculated total rate constant $\left(\mathrm{k}_{\mathrm{OH}}\right)$ values for hydrogen abstraction reactions of $3 \mathrm{H} 2 \mathrm{~B}$ with $\mathrm{OH}$ radicals within a range of temperature $250-450 \mathrm{~K}$ along with experimental data are presented in table 6 . It can be seen from table 6 that our calculated $\mathrm{k}_{\mathrm{OH}}$ value at $298 \mathrm{~K}$ using $\operatorname{CCSD}(\mathrm{T}) / 6-311++\mathrm{G}(\mathrm{d}, \mathrm{p})$ barrier heights is $1.20 \times$ $10^{-11} \mathrm{~cm}^{3}$ molecule ${ }^{-1} \mathrm{~s}^{-1}$ which is in good agreement with the experimental value of $1.03 \times 10^{-11}$ and 0.96 $\times 10^{-11} \mathrm{~cm}^{3}$ molecule $\mathrm{s}^{-1} \mathrm{~s}^{-1}$ reported by Aschmann et $a l .{ }^{14}$ and Messaadia et $a l .{ }^{23}$, respectively. The calculated rate constant values for the reaction between $3 \mathrm{H} 2 \mathrm{~B}$ with $\mathrm{OH}$ radicals in the temperature range of $250-450 \mathrm{~K}$ is fitted in the two parameter model eqn. and found to be well described by the following equation:

$$
\mathrm{k}_{\mathrm{OH}}=7.56 \times 10^{-11} \exp [-(549.3 \pm 11.2) / \mathrm{T}]
$$

The correlation coefficient $\left(\mathrm{R}^{2}\right)$ value for the fitting is 0.998 indicating the goodness of this model equation in representing the rate constant values in the said temperature range. The branching ratios for reactions (R1R4) are calculated using Eq. (6) and found to be $2.0 \%$, $93.0 \%, 1.8 \%$ and $3.2 \%$, respectively at $298 \mathrm{~K}$. The calculated branching ratio values clearly indicate the dominance of $\mathrm{H}$-abstraction from $-\mathrm{CH}$ group attached to hydroxyl group to the overall rate constant compare to its counterparts. Hence our calculation predicts reaction $\mathrm{R} 2$ as the major reaction channel as observed from the experimental study of Messaadia et al. ${ }^{23}$

\subsection{Atmospheric implications}

The atmospheric lifetime of $3 \mathrm{H} 2 \mathrm{~B}\left(\tau_{\mathrm{eff}}\right)$ can be estimated by assuming that its removal from the atmosphere occurs primarily through the reaction with $\mathrm{OH}$ radicals. Then $\tau_{\text {eff }}$ can be expressed as: ${ }^{47}$

$$
\tau_{\mathrm{eff}} \approx \tau_{\mathrm{OH}}
$$


Where, $\tau_{\mathrm{OH}}=\left(\mathrm{k}_{\mathrm{OH}} \times[\mathrm{OH}]^{-1}\right)$ and $[\mathrm{OH}]$ is the global average $\mathrm{OH}$ radical concentration in atmosphere. Taking the global average atmospheric $\mathrm{OH}$ radical concentration of $1.0 \times 10^{6}$ molecules $\mathrm{cm}^{48}$ and $\mathrm{k}_{\mathrm{OH}}$ value at $298 \mathrm{~K}$ as $1.20 \times 10^{-11} \mathrm{~cm}^{3}$ molecule ${ }^{-1} \mathrm{~s}^{-1}$, the atmospheric lifetime of $3 \mathrm{H} 2 \mathrm{~B}$ is estimated to be 1.04 days which is in very good agreement with the experimentally reported atmospheric lifetime of $3 \mathrm{H} 2 \mathrm{~B}$ with respect to the reaction with $\mathrm{OH}$ radicals by Messaadia et al. $^{23}$ (1.2 days).

\section{Conclusions}

We present here the potential energy profiles (including geometries, energies and vibrational frequencies of reactant, transition states and products) and kinetic data of $\mathrm{H}$ atom abstraction reaction of $3 \mathrm{H} 2 \mathrm{~B}$ with $\mathrm{OH}$ radical investigated at the $\mathrm{CCSD}(\mathrm{T}) / / \mathrm{BHandHLYP} /$ $6-311++\mathrm{G}(\mathrm{d}, \mathrm{p})$ level of theory. All the reactions were found to proceed by an indirect mechanism through formation of hydrogen bonded pre- and post-reaction complexes. The barrier height for reaction channels (R1-R4) calculated at $\operatorname{CCSD}(\mathrm{T}) / 6-311++\mathrm{G}(\mathrm{d}, \mathrm{p})$ level were found to be $4.73,480,-1.09,4.49,3.03$ and $3.39 \mathrm{kcal} \mathrm{mol}^{-1}$, respectively. The overall rate constant for the $\mathrm{H}$ atom abstraction of $3 \mathrm{H} 2 \mathrm{~B}$ by $\mathrm{OH}$ radicals was found to be $1.20 \times 10^{-11} \mathrm{~cm}^{3}$ molecule ${ }^{-1} \mathrm{~s}^{-1}$ at $298 \mathrm{~K}$ which is in good agreement with the available experimental data. A model equation has been proposed to describe the rate coefficients in a wide temperature range of $250-450 \mathrm{~K}$ as $\mathrm{k}_{\mathrm{OH}}=7.56 \times$ $10^{-11} \exp [-(549.3 \pm 11.2) / \mathrm{T}] \mathrm{cm}^{-3}$ molecule ${ }^{-1} \mathrm{~s}^{-1}$. The branching ratio results show that hydrogen abstraction from $-\mathrm{CH}$ group attached to hydroxyl group (R2) is thermodynamically and kinetically more facile than that of other reaction channels. This is further ascertained by bond dissociation energy calculation for $-\mathrm{C}-\mathrm{H}$ bonds. The $\Delta_{\mathrm{f}} \mathrm{H}_{298}^{0}$ values for $3 \mathrm{H} 2 \mathrm{~B}$ and $\mathrm{CH}_{2} \mathrm{COCH}$ $(\mathrm{OH}) \mathrm{CH}_{3}, \mathrm{CH}_{3} \mathrm{COC}(\mathrm{OH}) \mathrm{CH}_{3}, \mathrm{CH}_{3} \mathrm{COCH}(\mathrm{O}) \mathrm{CH}_{3}$, and $\mathrm{CH}_{3} \mathrm{COCH}(\mathrm{OH}) \mathrm{CH}_{3}$ radicals were calculated for the first time and found to be $-96.23,45.79,-57.85$, -38.19 and $-40.29 \mathrm{kcal} \mathrm{mol}^{-1}$, respectively at CCSD (T)/6-311++G(d,p) level. Atmospheric lifetime of 3H2B was estimated to be 1.04 days. These data can be useful for further thermo-kinetic modeling of other reactions involving these species.

\section{Acknowledgements}

BKM is thankful to University Grants Commission, New Delhi for providing Dr. D. S. Kothari Fellowship. NKG and HJS are thankful to Council of Scientific and
Industrial Research (CSIR), New Delhi for providing financial assistance.

\section{References}

1. Mendes J, Zhou C W and Curran H J 2013 J. Phys. Chem. A 1174515

2. Sebbar N, Bozzelli J W and Bockhorn H 2014 J. Phys. Chem. A 118(1) 21

3. Wolfe G M, Crounse J D Parrish J D, Clair J M St, Beaver M R, Paulot F, Yoon T P, Wennberg P O and Keutsch F N 2012 Phys. Chem. Chem. Phys. 147276

4. El Dib G, Sleiman C, Canosa A, Travers D, Courbe J, Sawaya T, Mokbel I, and Chakir A 2013 J. Phys. Chem. A 117117

5. Wildt J, Kobel K, Schuh-Thomas G and Heiden A C 2003 J. Atmos. Chem. 45173

6. Schauer J J, Kleeman M J, Cass G R, and Simoneit B R T 2001 Environ. Sci. Technol. 351716

7. Baugh J, Ray W, Black F and Snow R 1987 Atmos. Environ. 212077

8. de Andrade M V A S, Pinheiro H L C, Pereira P A D and de Andrade J B 2002 Quim. Nova. 251117

9. Calvert J G and Madronich S J 1987 Geophys. Res. 92 2211

10. Mousavi M and Seyfi H 2011 Org. Chem. J. 117

11. Koprowski M, Luczak J and Krawczyk E 2006 Tetrahedron $\mathbf{6 2} 12363$

12. Hayakawa R, Sahara T and Shimizu M 2000 Tetrahedron Lett. 417939

13. Palomo C, Oiarbidea M and Garcia J M 2012 Chem. Soc. Rev. $\mathbf{4 1} 4150$

14. Aschmann S M, Arey J and Atkinson R 2000 J. Phys. Chem. A 1043998

15. Galano A 2006 J. Phys. Chem. A 1109153

16. Dillon T J, Horowitz A, Holscher D, Crowley J N, Vereecken L and Peeters J 2006 Phys. Chem. Chem. Phys. 8236

17. Baasandorj M, Griffith S, Dusanter S and Stevens P S 2009 J. Phys. Chem. A 11310495

18. Messaadia L, El Dib G, Ferhati A, Roth E and Chakir A 2012 Chem. Phys. Lett. 52916

19. Butkovskaya N I, Pouvesle N, Kukui A, Liu R Z and Bras G L 2006 J. Phys. Chem. A 11013492

20. Baker J, Arey J and Atkinson R 2004 J. Phys. Chem. A 1087032

21. Wu Y Y, Chen K, Pan D T, Zhu J W, Wu B and Shen Y L 2011 J. Chem. Eng. Data 562641

22. Wren J C and Glowa G A 2000 Radiat. Phys. Chem. 58 341

23. Messaadia L, El Dib G, Lender M, Cazaunau M, Roth E, Ferhati A, Mellouki A and Chakir A 2013 Atmos. Environ. 77951

24. Becke A D 1993 J. Chem. Phys. 981372

25. Lee C, Yang W and Parr R G 1988 Phys. Rev. B 37 785

26. Yu A Y and Zhang H X 2013 J. Mol. Model. 194503

27. Prasanthkumar K P, Suresh $\mathrm{C} H$ and Aravindakumar C T 2013 J. Phys. Org. Chem. 26510

28. Prasanthkumar K P, Suresh C H and Aravindakumar C T 2012 J Phys Chem A 11610712 
29. Galano A. Alvarez-Idaboy J R and Francisco-Marquez M 2010 J. Phys. Chem. A $\mathbf{1 1 4} 7525$

30. Gonzales C and Schlegel H B 1991 J. Chem. Phys. 95 5853

31. Scuseria G E and Schaefer H F 1989 J. Chem. Phys. 90 3700

32. Pople J A, Gordon M H and Raghavachari K 1989 J. Chem. Phys. 875968

33. Mishra B K, Chakrabartty A K, Bhattacharjee D and Deka R C 2013 Struct. Chem. 241621

34. Mishra B K, Chakrabartty A K and Deka R C 2013 Mol. Phys. 112 1512. doi: 10.1080/00268976.2013.842008

35. Gomez M C, Iuga C and Alvarez-Idaboy J R 2012 Int. J. Quant. Chem. 1123508

36. Ang-yang Yu 2014 Struct. Chem. 25607

37. Frisch M J et al. Gaussian 09 Revision- B.01 Gaussian, Inc., Wallingford C T, 2009

38. Hammond G S 1955 J. Am. Chem. Soc. 77334
39. Chase M W Jr. 1998 J. Phys. Chem. Ref. Data Monograph 91

40. DeTar D F 1991 J. Org. Chem. 561478

41. Yamada T, Bozzelli J W and Berry R J 1999 J. Phys. Chem. A 1035602

42. Hudzik J M and Bozzelli J W 2012 J. Phys. Chem. A 1165707

43. Laidler K J 2004 In Chemical kinetics, $3^{\text {rd }}$ edn. (Delhi: Pearson Education)

44. Johnston H S and Heicklen J 1962 J. Phys. Chem. 66 532

45. Chuang Y Y and Truhlar D G 2000 J. Chem. Phys. 112 1221

46. Truhlar D G 1991 J. Comput. Chem. 12266

47. Papadimitriou V C, Kambanis K G, Lazarou Y G and Papagiannakopoulos P 2004 J. Phys. Chem. A 108 2666

48. Atkinson R 1997 J. Phys. Chem. Ref. Data 26215 